DOI: 10.33184/YVDK-2021-04-30.62

А.А. Субботина (магистрант, ЧелГУ, г. Челябинск)

\title{
РЕАЛИЗАЦИЯ КОНЦЕПТА СТРАХ В МАТЕРИАЛАХ АНГЛОЯЗЫЧНЫХ И РУССКИХ СЛОВАРЕЙ
}

В статье рассматривается эмоциональный концепт СТРАХ в английском и русском языках. Исследуются и сравниваются его синонимичный ряд, а также понятия на материале англоязычных и русских словарей. Автор приходит к выводу, что эмочиональный конщепт СТРАХ в английском языке имеет три уровня значений, не схожих между собой. В русском языке СТРАХ, в большинстве случаев, имеет негативную эмоциональную окраску.

Ключевые слова: страх, концепт, эмоция, эмоциональный концепт, словарь,

The article deals with the emotional concept FEAR. The aim of the work is to study its definitions and synonyms represented in English and Russian dictionaries. The author dwells on various meanings of the concept FEAR which are represented in chosen dictionaries. The author comes to the conclusion that in English there are three definition levels of the emotional concept FEAR which have not similar semantic zones. Nevertheless, it stands out from Russian connotation which usually has negative meaning of the studied concept.

Key words: fear, concept, emotion, emotional concept, dictionary.

Считается, что каждому человеку определенная эмоция присуща в той, или иной степени. Несмотря на это, одной из фундаментальных эмоций является страх. Это доминантная эмоция, базовая. Страх развивался вместе с человечеством на протяжении многих тысячелетий: страх перед голодом, перед войной, перед потерей близких, перед неудачной карьерой, перед неизвестным будущим. Данная эмоция универсальна, но 
представления народов мира о ней различались всегда [Шафигуллина 2012].

Долгое время эмоциональный концепт в составе языка не развивался. Изучалась, в основном, интеллектуальная составляющая в языке. Тем не менее, было важно обратить внимание на то, что эмоции, несомненно, оказывают значительное влияние на восприятие людьми окружающего мира, a, следовательно, и на порождение речи. Так, сформировалась наука эмотиология, изучающая взаимосвязи языка и эмоций [Шаховский 2008: 57].

Таким образом, нам представляется возможным провести анализ синонимичного ряда концепта СТPAX в английском и русском языках. Сравнить определения перечисленных синонимов. Это позволит исследовать эмоциональную составляющую данного концепта в английской и русской лингвокультурах.

Для проведения нашего исследования мы выбрали четыре известных словаря английского языка и рассмотрели представленные в них определения.

Определение изучаемого концепта, представленное в Cambridge Dictionary: a strong, unpleasant feeling that you get when you think that something bad, dangerous, or frightening might happen [Cambridge Dictionary].

Сильное, неприятное чувство, которое вы испытываете, когда вы считаете, что нечто плохое, опасное, или пугающее может произойти. (здесь и далее перевод наш, А.С.)

Macmillan Dictionary: the feeling that you have when you are frightened [Macmillan Dictionary]. Чувство, которое вы испытываете, когда напуганы.

Oxford Learner's Dictionaries: the bad feeling that you have when you are in danger or when a particular thing frightens you [Oxford Learner`s Dictionaries]. Плохое чувство, которое вы испытываете, когда вы в опасности или что-либо пугает вас.

Merriam-Webster Dictionary: an unpleasant often strong emotion caused by anticipation or awareness of danger [MerriamWebster Dictionary]. Неприятная, часто сильная эмоция, вызванная неприятным чувством ожидания опасности.

Также следует рассмотреть синонимы изучаемого концепта. Воспользуемся онлайн-словарем “Thesaurus”. Он 
предлагает следующие синонимы: scare, horror, terror, dread, phobia, fright, panic, jitters, affright, pavor, apprehension, suspicion, unease [Thesaurus].

Как мы видим, данные определения имеют ярко выраженную негативную коннотацию. Страх связан со смертью, угрозой жизни и здоровью, а также опасением, угнетенностью, настороженностью [Шафигуллина 2012].

Однако семантика изучаемого концепта связана не только c отрицательными эмоциями в английском языке. Это подчеркивает Кэррол Эллис Изард, доктор психологических наук из США. В своей книге «Психология эмоций» он говорит о том, что страх имеет адаптивную, социальную функцию, которая способствует мобилизации сил человека, способствуя уменьшению риска стать жертвой неконтролируемой ситуации. Страх мотивирует к поиску безопасной среды, что позволяет лучше смоделировать свое поведение [Изард 2012: 308 - 316].

Рассмотрим определения и синонимы слова СТРАХ с позиции теории Изарда.

Следующую дефиницию данному концепту предоставляет Merriam-Webster Dictionary. Fear - anxious concern: solicitude [Merriam-Webster Dictionary]. Solicitude передает следующие эмоции: волнение, беспокойство.

Oxford Learner's Thesaurus (A dictionary of synonyms) так же дает такие синонимы: aid, business concern, headache, attention, concern, caution, precaution, forethought, care, guardianship, tutelage, angst, trepidity, responsibility, worry [Oxford Learner's Thesaurus].

На примере изученных синонимов мы модем сделать вывод, что в данном случае изучаемый нами концепт имеет менее отрицательную коннотацию, чем первый уровень его значения, который передает исключительно страх перед смертью, перед угрозой здоровью.

Второй уровень выражает обеспокоенность (aid, angst, anxiety, business concern, caution, concern, headache, precaution, trepidity, worry), a также заботу, желание защитить близкого человека (aid, attention, care, forethought, guardianship, tutelage). Важно то, что страх сравним с ответственностью (responsibility), что определенно не является отрицательным определением. 
В ходе исследования определений и синонимичного ряда слова СТРАХ в словарях, мы выделили третий уровень значений и синонимов.

Merriam-Webster Dictionary дает следующее значение существительного «страх»: profound reverence and awe especially toward God (глубокое уважение и трепет, особенно к Богу) [Merriam-Webster Dictionary].

Collins online dictionary предлагает следующее определение концепта СТРAX, находящееся на третьем уровне его значений: а feeling of profound respect for someone or something (чувство глубокого уважения по отношению к кому-то или к чему-то) [Collins online dictionary].

Вышесказанный словарь предоставляет очередной ряд синонимов, употребляющихся со словом СТРАХ: awe, reverence, veneration. Перечисленные слова имеют одинаковую семантику, они означают преклонение перед кемлибо великим. Например, правителем или Богом.

Рассмотрим пример употребления слова "veneration", представленном в Cambridge Dictionary: "veneration of ancestors was very important in Celtic religion" [Cambridge Dictionary].

Cambridge English Corpus приводит следующие случаи использования слова "reverence": reverence for the moral law (почитание закона морали), religious reverence (почитание религии), reverence to a higher power (почитание высшей силы), reverence the professors (почитание профессоров) [Cambridge English Corpus].

Более того, приводится ряд выражений, в которых могут употребляться данные слова и в вышеупомянутом онлайн-словаре Cambridge English Corpus: the fear of God (почитание Бога), the Chinese reverence for the dead (почитание мертвых в Китае), the French treat food with gentle reverence (во Франции относятся к еде с почитанием), his respect for the law bordered on veneration (его уважение закона было схоже с почитанием) [Cambridge English Corpus].

В ходе анализа приведенных дефиниций, а также синонимичного ряда, можно с уверенностью сказать, что на третьем уровне значений концепт СТРАХ приобретает положительную коннотацию, что, несомненно, отличается от 
первого и второго уровня. Данный уровень связан с уважением к кому-либо вышестоящему: Богу, предкам, правителям.

Рассмотрим значение слова СТРАХ в русском языке.

В Большом словаре русского языка, составленным С.А. Кузнецовым, основным значением слова СТРАХ является следующее: 1. Это состояние сильной тревоги, беспокойства, душевного смятения перед какой-либо опасностью, бедой. 2. Чрезвычайно, сильно, много [Большой словарь русского языка 1998: 978].

Далее, Новый словарь русского языка под редакцией Т.Ф. Ефремовой дает следующие определения страху: 1. Состояние сильной тревоги, боязни, беспокойства, душевного волнения от грозящей или ожидаемой опасности. 2. Выражение, проявление тревоги, беспокойства, боязни 3. То, что вызывает сильную боязнь, тревогу, беспокойство. 4.Кто-л., что-л., представляющие угрозу для кого-л. 5. Крайне, чрезвычайно, очень сильно [Новый словарь русского языка 2000: 1548].

Также рассмотрим его определение в Толковом словаре С.И. Ожегова: 1. Очень сильный испуг, сильная боязнь. 2.События, предметы, вызывающие чувство боязни, ужаса. 3.Очень, в высшей степени, очень много [Толковый словарь Ожегова].

Толковый словарь живого великорусского языка В.И. Даля дает следующие определения: 1. Страсть, сильное опасенье, боязнь, робость, тревожное состоянье души от испуга, от грозящего или воображаемого бедствия. 2. Много, без числа, несметно, тьма, пропасть [Толковый словарь живого великорусского языка Даля].

Обратим внимание на то, что в основном определения имеют отрицательную коннотацию. Однако есть и определения, которые не употребляются в английском языке. Это случай, когда «страх» приравнивается к «много».

Для более точного анализа восприятия концепта СТРАХ необходимо изучить синонимы данного слова.

Словарь русских синонимов Н.П. Абрамова беспокойство, страх, паника, опасение, оторопь, дрожь, трепет, боязливость, малодушие, мнительность, робость, трусость, испуг [Словарь русских синонимов]. 
Словарь синонимов русского языка 3.Е. Александровой предоставляет следующий ряд синонимов: паника, фобия, жуть, испуг, фобос, ужас, тревога, опасение, опаска, боязнь, ужасть [Словарь синонимов русского языка 2020: 683].

Наконец, исследуем синонимы, перечисленные в онлайнсловаре русских синонимов: ужас, боязнь, трепет, жуть, страсть, опасение, опаска, испуг, перепуг, тревога, фобия.

Особый интерес предоставляет тот факт, что все вышеперечисленные синонимы, как и определения изучаемого концепта, являются отрицательными, а связаны они лишь с эмоциональным состоянием.

Следующим этапом исследования семантики слова СТРАХ является составление ряда фраза, в которых оно употребляется.

Так, например, словарь Кузнецова дает следующие варианты использования слова СТРАХ в контексте: Дрожать от страха. Натерпеться страху. Страх за любимую. Панический страх.

Животный страх. Под страхом смерти. Страх потерять работу. Страх перед экзаменом. Ребенок страх как любит сладкое. Она страх как любит петь. Страх как хочется поспать. Она ревнива страх! Он страх какой важный [Большой словарь русского языка 1998: 978].

Как мы можем заметить, Кузнецов перечисляет большее количество случае употребления слова СТРАХ, он расширяет поле употребления, используя его не только в выражениях, связанных со смертью, угрозой жизни и здоровью, но и со страхами перед неизвестным (работа, учеба).

Рассмотрим примеры, приведенные в Толковом словаре живого великорусского языка В.И. Даля: Страх обуяет и растеряешься. Со страху поджилки дрожат. Слепой страх, панический. Страх смерти. Страху в глаза гляди. Держать коголибо в страхе. Страх, что народу было! Страх не люблю дождь [Толковый словарь живого великорусского языка Даля].

Словарь Ожегова предлагает следующие варианты употребления слова СТРАХ: Нагнать страху. Держать под страхом. У страха глаза велики. Чтоб враги боялись. Страх за детей. Грибов в лесу страх! Страх какой дождик! Страх какой сердитый! Страх как испугался! [Толковый словарь Ожегова]. 
Рассмотрев понятия, синонимичный ряд, а также употребление изучаемого концепта в контексте русского языка, мы можем утверждать, что СТРАХ в русском языке имеет два семантических уровня. Первый уровень универсален, он связан с опасением за свою жизнь, за жизнь близких людей. Второй уровень является обстоятельством меры и степени. Это часть устойчивого разговорного выражения, передающая значение «очень».

Таким образом, проанализировав несколько значений изучаемого нами концепта, мы можем выделить 3 уровня употребления слова СТРАХ в английском языке, которые полностью отличаются друг от друга по коннотации (отрицательная, нейтральная, положительная).

СТРАХ в русском языке наоборот, имеет более узкое, универсальное семантическое поле.

Проанализировав концепт СТРАХ в английском и русском языке, мы пришли к выводу, что их понимание в разных языковых картинах мира значительно отличается. В английской лингвокультуре значение концепта СТРАХ, помимо опасности смерти, связано с тревогой, волнением, желанием защитить своих близких, взять над ними опеку. Не менее важным значением является почитание вышестоящих лиц, священных предметов, норм морали. В русском же языке концепт СТРАХ является наиболее базовым, либо не имеет собственной семантики вообще (на втором уровне), являясь частью устойчивого выражения.

\section{ЛИТЕРАТУРА}

1. Болышой словарь русского языка / сост. С.А. Кузнецов. - Санкт-Петербург: Норинт, 1998. $-1534 \mathrm{c}$.

2. Изард Э.К. Психология эмоций: пер. А. Татлыбаевой. - Санкт Петербург: Питер, 2012.-465 с.

3. Новый словарь русского языка: Толково-словообразовательный / Т. Ф. Ефремова. - М.: Русский язык, 2000.-T.1.-1210с.

4. Онлайн словарь русских синонимов. [Электронный ресурс]. https:/synonymonline.ru (дата обращения: 4.04.2021).

5. Словарь русских синонимов / сост. Н.П. Абрамов. [Электронный ресурс]. URL: http//gramota.ru/slovari/info/abr (дата обращения 2.04.2021).

6. Словарь синонимов русского языка / сост. 3.Е. Александрова. - Москва, Новые словари, 2020. -816 с. 
7. Толковый словарь живого великорусского языка Даля / сост. В.И. Даль. [Электронный ресурc]. URL: http://slovardalja.net (дата обращения: 29.03.2021).

8. Толковый словарь Ожегова. [Электронный ресурс]. URL: https:/slovarozhegova.ru (дата обращения: 28.03.2021).

9. Шафигуллина И.И. Репрезентация концетта СТРАХ в современной лингвокультуре // ВестникКазанского технологического университета. 2012. № 5.5 [Эектронный pecypc]. https:/cyberleninka.ru/article/n/reprezentatsiya-kontsepta-strah-v-sovremennoylingvokulture (дата обращения 14.03.2021).

10. Шаховский В. Лингвистическая теория эмоций: Монография. - Москва: Гнозис, 2008. - 416с.

11. Cambridge dictionary. [Электронный pecypc]. URL: https:/dictionary.cambridge.org (дата обращения: 1.03.2021).

12. Cambridge English Corpus. [Электронный pecypc].URL: https:/www.cambridge.es/en (дата обращения 5.03.2021).

13. Collins online dictionary. [Электронный pecypc]. URL: https:/www.collinsdictionary.com(дата обращения: 4.03.2021).

14. Macmillan Dictionary and Thesaurus: Free English Dictionary Online. [Электронный ресурc]. URL: http:/www.macmillandictionary.com (дата обращения: 1.03.2021).

15. Macmillan English Dictionary for advanced learners / M. Rundell. - Macmillan, 2007.-1748p.

16. Merriam-Webster Online: Dictionary and Thesaurus. [Электронный ресурc]. URL: http:/www.merriam-webster.com/dictionary (дата обращения 2.03.2021).

17. Oxford Learners Dictionaries. [Электронный pecypc]. URL: http://oxfordlearnersdictionaries.com (дата обращения: 6.03.2021).

18. The Edinburgh Associative Thesaunus. [Электронный ресурc]. URL: http:/rali.iro.umontreal.ca/word-associations/query (дата обращения: 7.03.2021).

19. The Oxford Thesaurus. An A-Z Dictionary of Synonyms. - Oxford, 2004 - 2062 p.

20. Thesaurus. [Электронный ресурc]. URL: https:/www.thesaurus.com (дата обращения: 11.03.2021). 